\title{
OVERCOMING THE FINANCIAL AID BARRIER FOR E-LEARNERS
}

\author{
Bruce Chaloux \\ Electronic Campus \\ Southern Regional Education Board
}

\begin{abstract}
Financial aid systems help make higher education available to all who can benefit. To "adjust" the existing financial aid system to make it more student friendly and open doors currently closed to many part-time learners and students with the greatest financial challenges, state policy changes and greater private sector initiatives targeted at workforce can use creative strategies, including altering state-based programs, creating new learning tax incentives, coordinating employer-based aid, and distributing aid directly to students.
\end{abstract}

\section{KEYWORDS}

Financial Aid, Part-Time Learners, Policy, State-Based Programs, Tax Incentives, Employer-Based Aid, Direct Distribution

\section{INTRODUCTION}

Only two decades ago, federal and state financial aid "filled the gap" between a student's (or typically his/her parents) ability to pay and the cost of attending college, particularly for institutions in the public sector. That aid, in an era of traditional-aged, full-time, residential students made sense. It provided the financial wherewithal for a generation of first-time college goers with a pathway to the American dream of a college education. Millions of dollars have become billions, tuition and fees have risen dramatically during the past five years, and debt-significant levels of debt-now burden families and graduates entering the workforce. No longer is indebtedness a feature of graduate or professional students, but now is a burden to a growing number of freshmen. Federal and state financial aid programs no longer fill gaps, but rather provide only a small, and inadequate, "cushion" against financial need. While some would argue the point, we may be seeing the beginning of the end of an egalitarian system of higher education that afforded everyone capable of succeeding the opportunity for a higher education. The irony, of course, is that the same federal financial aid programs that fueled much of the growth in higher education might now be an impediment by failing to adjust to the changing student environment.

More troublesome in the escalating financial aid crisis may be the impact on the growth and evolution of online learning and ALN. While ALN still serves a predominantly traditional student population, it offers greater access to a lifetime of learning and a primary delivery method for the current generation of savvy students who have learned outside the traditional classroom via technology. It is logical to believe that when the current wave of students enter the job market and seek to continue their education, whether to pursue an advanced degree or to seek certification, they will give serious consideration to the convenience of ALN. For some, particularly those attempting to balance work, family and education, the lack of access to financial aid, at least through traditional federal and state sources, becomes a significant barrier. It is a barrier that grows each year, exacerbated by the increasing cost of pursuing a higher education. It must be addressed. It won't be easy. 
Online and distance learning has clearly provided greater access for many students, both those pursuing full-time study on campus and, more recently, for working adults and other "non-traditional" learners. Students are older, increasingly more women are participating, and many more students are engaging in learning on a part-time basis. And while working students save money on such items as travel to and from campus and dependent care expenses through online learning, the greatest benefit is not having to resign one's job and lose a source of income or completely relocate in order to pursue higher education. But actual tuition and related equipment costs for distance learning programs may, in fact, be higher than oncampus courses. Computers, Internet access and "technology" fees are often added to the price of online courses. Ironically, these added expenses create problems for the students who could most benefit from online courses.

Despite overwhelming data suggesting that most students now work while attending college (75\%) and the number of traditional-aged full-time in-residence students continues to decline, the current financial aid "system" serves, almost exclusively, the remaining $25 \%$ of the student population. Moreover, most colleges and universities now depend on this federal and state financial aid "system" to support their fulltime, campus-based students, rejecting any and all efforts to provide support for part-time and online learners. Little aid is available to the distance learner, and even less if the student is not enrolled half-time or admitted to a degree program. Financial aid mechanisms, established over the past 40 years and designed to expand access, often limit aid for students who are the neediest. Structures, policies, procedures and practice have become real barriers to getting aid to the fastest growing population of students in U.S. higher education. These barriers, many engrained in federal, state and institutional policy, will not be easily removed, if even adjusted in any significant way.

Three years ago, the Southern Regional Education Board's Distance Learning Policy Laboratory issued a report on the impending financial aid crisis for distance learners. The report targeted action in the then upcoming Reauthorization of the Higher Education Act. That target has proven elusive as there is still no immediate timetable for action by the U.S. Congress in 2005. Further, despite efforts by many to influence significant changes in current federal financial aid programming, including the $2000 \mathrm{Web}-$ Based Commission Report and the results of the U.S. Department of Education's Distance Education Demonstration Projects, most Washington insiders suggest only minor changes, if any, should be expected. It seems clear that change, significant policy change at the federal level, is highly unlikely.

\section{SOME ALTERNATIVE APPROACHES}

In the aforementioned SREB report, principles to guide the future development of financial aid to support distance learners were suggested. The principles included:

- The broader and fundamental goal of financial aid systems at all levels is to make higher education available to all who can benefit and to remove or lessen financial hurdles to such access.

- Any financial aid system must be fair and reasonable to all learners. Financial aid policy should encompass a broader definition of "student learner" than the current traditional classifications.

- With learning no longer confined to a campus setting in face-to-face classrooms or in defined blocks of time, policy built around that model is fundamentally flawed.

- Students are increasingly learning in part-time, extended and contracted time formats and these new learning arrangements should not penalize or exclude participating learners from access to financial aid.

- Financial aid systems must become more student-centric and responsive to how, where, and when students learn. 
Blended Learning and Localness: The Means and the End

- Appropriate accountability mechanisms to prevent fraud and abuse must be maintained.

These principles, certainly not radical, might have a chance to be implemented at the state level or through state efforts to encourage changes in support for distance learners. Four specific initiatives are suggested.

\section{A. Altering State-Based Programs}

States generally provide financial aid for a variety of purposes beyond those of the federal system, including need-based programs and a growing number of programs for academically talented students. Georgia's HOPE scholarship, established in 1993 is one example of a program designed to both reward talented students and to keep the state's brightest at home. The merit-based program has been successful and has been replicated in a number of states across the country. Those programs can be adjusted to accommodate distance learners, part-time adult learners, or other groups of students with limited financial aid support. One model that holds promise is Vermont's "Non-Degree Grant" program that provides direct state financial aid to Vermont residents to cover tuition and fee costs. Coursework can be taken from a variety of course providers, including colleges and universities, technical centers, private training organizations and high schools. Support is provided for coursework designed to improve employment skills or to be a "stepping stone" to pursuing a degree. Unlike other federal and state programs that require a student be formally admitted and enrolled in a degree program and making "satisfactory progress," this program invests state dollars in citizens and "kick starts" their educational efforts. This initiative, part of a broader effort by that state to support adult learners, is commendable.

\section{B. Creating New Learning Tax Incentives}

Another approach is for states to offer incentives such as tax credits to employers to encourage and support employee educational initiatives. Education is good for individuals and for business. Distance learning has the added benefit of allowing workers to better balance work, family and educational responsibilities and may permit them to stay on the job while pursuing studies. The broader community and social benefits offer real value as well: research indicates that individuals with more education are more apt to vote, are less likely to be incarcerated, are more likely to volunteer and contribute more to the tax base. The investment made is returned in multiple ways. Further, incentives to participate in distance learning will support skills learned by participating in online learning to the work environment. While many older students are leery of and at times intimidated by the online environment, some research is suggesting that these same students are being empowered by gaining familiarity with technology and that it is having a positive affect on job performance. Kentucky created a tax incentive for employers to encourage more adults to complete GED programs and enter postsecondary education (including the Kentucky Virtual University), but the program was slowed by "red tape" and it being retooled. Still, it holds promise as a strategy to encourage educational pursuits for many workers.

\section{Coordinating Employer-based Aid}

A related effort that has emerged over the past decade is employer-financed education-an increasing trend as learning has became more mobile, initially through branch campuses and off-campus centers and more recently via various technology. Employer-supported education is often focused on specific skills applicable to the job rather than broader degree goals of the individual, although many employers support both. The changing nature of work results in outdated skills. Employers who recognize that human resource development is the key to competitive advantage are more likely to support tuition reimbursement. Some find it is often easier and less expensive to outsource the training to a college or university and subsidize worker (student) participation in these programs. Data show that rather than 
losing employees once they complete certificate and degree programs, employees are actually more likely to stay with the company that subsidizes their education. An organization benefits by saving money by not having to develop the curriculum, by reducing turnover and by developing workplace skills necessary to meet its performance goals.

With more companies desirous of recruiting and retaining their workforce, more have enticed employees to pursue part-time studies while working. The recent emergence of IT certifications is an example of this - companies have spent huge sums of money supporting their employees to secure various IT network and system certifications. While not financial aid in the traditional sense, employers, as part of work compensation packages, have provided support for up to the entire cost of tuition and fees (or perhaps some percentage based upon factors such as the grade earned in a course), thereby investing in their employees. Employer-based support continues to grow, effectively making higher education a "nocost" or "low-cost" fringe benefit for some employees. The IRS allows public and private employers to provide up to $\$ 5,250$ per year to each employee in a tax-free reimbursement for educational expenses and is another powerful tool to support employer-based efforts. Too few individuals and businesses know about this program and therefore many fail to take advantage of it.

\section{Direct Aid Distribution to Students}

Without question the most radical proposal is not a new idea, but one that has gained little support from most traditional colleges and universities, for obvious reasons: distributing aid directly to the student. Establishing direct aid to students, more often seen in private scholarship programs, could provide new options for learners to utilize assistance as they deem appropriate (as is the case in the Vermont program referenced earlier). Such an approach could simplify the aid process and address challenges and problems relating to time, cost of education and other regulations that are part of more traditional aid programs that simply don't work for many part-time and e-learners. Appropriate oversight mechanisms would need to be developed to protect against fraudulent practices and the problems of tracking progress and the use of aid proceeds. A challenge might be how to scale such efforts. Still, targeting support to assist learners through direct financial grants can encourage more participation. States might use such a program to engage more students in areas where there are shortages (e.g. teaching) and where they can utilize workforce development agencies/offices and work with local communities. These grants could then be "forgiven" for students who work in targeted disciplines, specific job categories or in designated geographic areas.

\section{A TIME TO ACT}

Now is the time for creative strategies and bold initiatives to "adjust" the existing financial aid system to make it more student friendly, to extend and encourage greater participation for "nontraditional" students and to support the growing use of technology for providing higher education. Absent major federal changes, highly unlikely in the short term, encouraging state policy changes and greater private sector initiatives targeted at workforce needs may be a realistic option. Removing financial barriers through new financial aid "vehicles" will open doors currently closed to many part-time learners and students with the greatest financial challenges.

\section{ABOUT THE AUTHOR}

Bruce Chaloux directs the 16-state Electronic Campus initiative of the Southern Regional Education Board. The Electronic Campus, the South's "electronic marketplace" for distance education courses and programs, has grown to include over 7,000 courses and 250 degree programs from more than 325 colleges 
and universities in the region. He also directs a FIPSE LAAP grant focusing on distance learning policy (SREB's Distance Learning Policy Laboratory).

Prior to assuming his duties at the SREB, he served in the Graduate School at Virginia Tech for 13 years, including nine years as Associate Dean and Director of Tech's Northern Virginia Graduate Campus and four years as Associate Dean for Extended Campus Programs in Blacksburg.

Dr. Chaloux has nearly 30 years of teaching and administrative experience in higher education at the institutional, state, and national levels. He taught an occasional graduate course and directed six doctoral students while at Virginia Tech, served as a faculty member in Business and later as Associate Dean and Dean for Academic Affairs at Castleton State College in his native state of Vermont, was a staff member with Virginia's Council of Higher Education, and was Dean in Residence with the Council of Graduate Schools while on sabbatical from Virginia Tech in 1993-4.

His numerous professional assignments and activities include direction of a national project on the assessment of telecommunications (Project ALLTEL) in the mid-1980's, chair of the Southern Association of Colleges and Schools Committee on Distance Learning and the Council of Graduate School's Distance Learning Task Force, and serving on the Council for Academic Management for the eArmy $U$ initiative in addition to service on advisory boards, task forces and projects focusing on elearning. 